\title{
ÖĞRETMEN ALGILARINA GÖRE ÖRGÜTSEL GÜÇ MESAFESİ İLE ÖRGÜTSEL SİNERJİ DÜZEYİ ARASINDAKİ İLISSKİNIN İNCELENMESİ
}

\author{
Ebru ERSOY \\ Kültür Üniversitesi, Türkiye \\ ebrunote60@gmail.com \\ https://orcid.org/0000-0001-5989-0026 \\ Faruk LEVENT \\ Marmara Üniversitesi, Türkiye \\ faruk.levent@marmara.edu.tr \\ https://orcid.org/0000-0003-3429-6666
}

\section{ÖZ}

Bu araştırmanın amacı, öğretmen algılarına göre örgütsel güç mesafesi ile örgütsel sinerji düzeyi arasındaki ilişkinin incelenmesidir. Nicel araştırma yöntemlerinden ilişsisel tarama modelinin kullanıldığı bu araştırmanın örneklem grubu, 2018-2019 eğitim ve öğretim yılında İstanbul ili Zeytinburnu ilçesinde ilkokul, ortaokul ve liselerde görev yapan toplam 2635 öğretmen arasından seçkisiz basit tesadüfi örnekleme yöntemiyle belirlenen 330 öğretmenden oluşmaktadır. Veri toplama aracı olarak öğretmenlerin demografik verilerine ilişkin Kişisel Bilgi Formu, Örgütsel Sinerji Ölçeği ve Örgütsel Güç Mesafesi Ölçeği kullanılmıştır. Araştırma kapsamında elde edilen bulgulara göre Örgütsel Sinerji Ölçeği alt boyutları demografik verileri incelendiğinde yaşa, cinsiyete göre anlamlı farklılık görülmemiştir. Fakat Örgütsel Sinerji Ölçeği alt boyutlarından biri olan stratejide kıdeme göre anlamlı bir fark tespit edilmiştir. Ayrıca bu araştırmada diğer bir ölçek olan örgütsel güç mesafesi alt boyutları demografik verilere göre incelenmiştir. Örgütsel Güç Mesafesi Ölçeği alt boyutları kıdeme göre incelendiğinde, gücü araçsal kullanma, gücü meşrulaştırma ve güce razı olmada anlamlı farklılık saptanmıştır. Bununla birlikte örgütsel güç mesafesi ile örgütsel sinerji düzeyi arasında anlamlı bir ilişki bulunamamıştır.

Anahtar Kelimeler: Örgütsel Sinerji, Örgütsel Güç Mesafesi, Öğretmen.

\section{INVESTIGATION OF THE RELATIONSHIP BETWEEN ORGANIZATIONAL POWER DISTANCE AND ORGANIZATIONAL SYNERGY LEVEL ACCORDING TO TEACHERS' PERCEPTIONS}

\begin{abstract}
The purpose of this research is to investigate the relationship between organizational power distance and organizational synergy level according to teacher perceptions. The sampling group of this research, which uses the relational screening model, which is one of the quantitative research methods, consists of 330 teachers determined by random sampling method among 2635 teachers working in primary, secondary and high schools in Zeytinburnu district of Istanbul province in 2018-2019 academic year. Personal Information Form, Organizational Synergy Scale and Organizational Strength Distance Scale were used as data collection tools. According to the findings obtained in the study, when the demographic data of the Organizational Synergy Scale sub-dimensions were examined, there was no significant difference in terms of age and gender. However, a significant difference was found in the strategy, which is one of the subdimensions of the Organizational Synergy Scale, by seniority. In addition, in this research, the organizational power distance sub-dimensions, which is another scale, were examined according to demographic data. When the sub-dimensions of the Organizational Strength Distance Scale were analyzed by seniority, a significant difference was found in using power as an instrument, legitimizing power, and accepting power. However, there was no significant relationship between organizational power distance and organizational synergy level.
\end{abstract}


Keywords: Organizational Synergy, Organizational Power Distance, Teacher.

\section{GíRIȘ}

Okul yöneticileri kurumlarındaki eğitim-öğretim faaliyetlerini yönetirken aynı zamanda örgütsel hedeflere ulaşabilmek için öğretmenleri koordinasyon içerisinde yapılacak işlere yönlendirmede farklı strateji yollarına da başvurmaktadırlar. Bazı yöneticiler öğretmenleri bilgileriyle ve tecrübeleriyle inandırma yoluna giderken, bazı yöneticiler ise yasal gücün yetkisine dayanarak öğretmenleri etkilemeyi hedeflemektedir. Akçay'a (2003: 122) göre öğretmenleri etkilemenin yolları, etkilemenin önemi ve bu uygulamalara yönelik davranışları yöneticiler bilmeli ve okullarına entegre etmelidir.

Okul yöneticilerinin elinde bulundurdukları güç kaynaklarını iyi bilmesi ve okuldaki öğretmenlerin ellerindeki güç kaynaklarına ne şekilde davranacaklarını önceden tahmin etmesi, gücün etkinliği ve verimliliği açısından büyük önem arz etmektedir. Bu anlamda okul yöneticilerinden, güç kaynakları içinden en uygun olanını seçebilen ve gerektiği zaman elinde bulundurduğu gücü örgütün faydası için paylaşabilen bir lider olması beklenebilir (Polat, 2010: 21-22). Okul yöneticisi duruma göre elinde olan zorlayıcı güç, ödül ya da yasal gücü gibi güç türlerine ya da statüsünden kaynak alan gücü ile kişisel özelliklerinde bulunan karizmatik güç, uzmanlık ve bilgi gücünü de kullanabilmektedir (Aslanargun, 2009: 51). Altınkurt ve ark.'na (2014: 25) göre okul yöneticilerinin, çalışanları etkileyebilmek için kullandığ 1 güç kaynakları, sergilediği davranışlar ve çalışanlar ile arasındaki ilişkinin gücü, çalışanların örgüte ilişkin algısına ve başarısına etki etmektedir.

Okul örgütünde mevcut olan gücün paylaşılması örgüte katk1 sağlamaktadır (Kayalı, 2011: 11). Okul yöneticileri elinde bulundurduğu güç kaynaklarını kullanarak, üstlendikleri görevleri yerine getirebilmektedir. Okuldaki güç kaynakları, yöneticiler ve öğretmenler arasında paylaşıldığında oluşan sinerji ile daha da yüksek seviyeye çıkmaktadır (Taymaz, 2019: 72). Okuldaki gücün paylaşılması esnasında, okul yöneticilerinin bazı görevleri yerine getirmesi gerekmektedir. Örgüt amaçlarının gerçekleştirilmesinde büyük bir sorumluluk alan yöneticilere ait yeterlilikler ve nitelikler, örgüt üyelerini etkileme aracılığg ile örgütsel amaçlara yöneltmede önemli rol üstlenmektedir (Argon ve ark. 2014: 27). Örgütün amaçlarına ulaşması ve çalışanların bu amaçları gerçekleştirmesi için yönetici tarafından etkileme yoluyla amaçlara yöneltilmelidir. Bunun için yöneticilerin elinde bulunan güçleri etkili bir şekilde kullanması gerekmektedir (Uğurlu ve Demir, 2014: 2). Karaman'a (2009: 11) göre yöneticilerin, güç kaynaklarının konusunu, alanını, gücün hangi şartlarda elde edildiğini toplum üzerinde oluşan algısını ve önemini anlayabilmesi; sahip oldukları gücün okulun verimliliği ve etkililiği için kullanabilmeleri adına önem arz etmektedir.

Liderlerin ekip üyelerini harekete geçirmesi, liderlerin etkileyebilme güçleri ile doğrudan ilişkilidir (Güney, 1999: 33). Güç, diğer bireylerin davranışlarını etkilemede bireyin yeteneğidir. Güç bireyin kendiliğinden oluşur. Bu gücün kullanılmasında olduğu gibi diğer kaynakların ortaya çıkarılması da mümkündür (Can, 2011: 52). Bu durum yönetici ve iş görenler için kayda değer faktörlerdendir. Koçel (2015)'e göre gücün, yöneticileri motive ve tatmin edici bir özelliği vardır. Bertrant Russel ise ‘enerji kavramı' fizik kuramlarının ana yapısını teşkil ediyorsa, 'güç' olgusu toplum biliminin ana dinamiği olduğunu dile getirmiştir.

Türk Dil Kurumu (TDK) Sözlügünde güç, "fizik, düşünce ve ahlak açısından etki yapabilmek veya etkiye direnç gösterebilme gücü” olarak ifade edilebilmektedir (TDK, 2019). Sosyal hayatın ve sosyal dinamiğin vazgeçilmez bir özelliği ve sosyal bilimler için önemli bir kavramıdır (Turner, 2005: 1). Kutanış'a (2014: 145) göre güç, mutlak ve değişmez değildir. Literatürde güce ilişkin birçok tanımlamalar yapılmakla birlikte, Lunenburg ve Ornstein (2013: 25), güç genel ifade ile bireyleri etkileyebilme yeteneğidir.

Literatürde güç kavramı ile ilgili kuramcıların farklı güç tanımları yaptığı görülmektedir. Güç kavramının; ilgi, makam, kişilik, uzmanlık alanı, ödül, ceza, güçsüzlük (Açıkalın, 1993: 60) olarak tanımlandığı gibi çalışanı yetiştirme, bilgi verme, destek olma, yol gösterme, katılmayı teşvik etme, plânlama, emir verme ve ödüllendirme (Aydın, 2016: 11) olarak da açıklandığı anlaşılmaktadır. Şimşek ve ark.'ları (2015: 432) ise güç kavramını başkalarına tesir edebilme olarak ifade etmiştir. 
Raven (2008), güç kavramını sosyal bir güç olarak ele almış ve gücün figürünün değişimini gerçekleştirmek için uygun kaynakların kullanması olarak ifade etmiştir. Hâkim olma durumu ve itaat etme ile ilişkilendirilmiş olsa bile gerçekte örgütün sosyal hedeflerine ulaşması için bir kaynak niteliğindedir (Özaslan ve Gürsel, 2008: 70). Yönlendirme, tavsiye ve inandırma esaslı kontrole dayandırmaktadır. Bu kapsamda güç esas olarak liderin bir becerisidir. Otorite ise lidere sunulmuş bir yetki olarak değerlendirilmektedir.

Güç mesafesi kavramı, çalışanların yöneticilerden emir aldıklarında bu emirleri yerine getirirken nasıl davrandıkları ile toplumda ve örgütlerdeki güç dağılımındaki eşitsizliğin algılanma biçimi ile ilişkilidir. Terzi'ye (2004: 66) göre güç kaynaklı farklılıkları en aza indirgemek için uğraşan topluluklar, güç mesafesinin düşük olduğu kültürde; gücün kurumsallaştığı topluluklar ise güç mesafesinin yüksek bulunduğu kültürde tanımlamaktadır.

Güç mesafesinin yüksek olduğu durumlarda, yöneticilerin verdiği emirler sorgulanmadan uygulanır. Bu kültürde, statü, unvan ve pozisyon gibi belirleyici özelliklere fazlaca değer verilmektedir. Ast-üst ilişkisi arasında bulunan mesafe örgütlerde hissedilir düzeydedir. Güç mesafesinin düşük olduğu durumlarda ise kişiler kendilerine yöneticiler ile eş değer olarak görmektedir (Özgener, Ögüt ve Kaplan, 2008: 98). Gücü elinde tutan kişilere yaklaşmak ve yakınlaşmak daha kolaydır. Sofyalıŏlu ve Aktaş (2001: 86) yöneticinin bireylere emir verebilmesi için, emir verdiği konuda, bireylerden daha fazla bilgili olması gerektiğini belirtmişlerdir.

TDK Sözlüğünde sinerji; "bir sonuca katklsı olabilecek birkaç etkinin belirli bir etkileşim sonucunda elde edilen ortak güç" şeklinde tanımlanmaktadır (TDK, 2019). Sinerji, kişilerin kendi kendilerine üretebileceklerinin toplamından çok daha fazla üretebilmektir. Cüceloğlu'ya (2008) göre sinerji, bütünün parçaların toplamından daha büyük olduğunun ifadesidir. Bütünü meydana getiren parçalar arasındaki bağlantılar, parçalara bağımlı olmayan bir anlam ifade eder ve bütüne anlam verirler. Parçalar bu bağlantılar sayesinde anlam verir ve diğer parçalarla birleşir.

Literatür incelendiğinde öğretmenlerin örgütsel güç mesafesi ile örgütsel sinerji düzeyi arasındaki ilişkiyi inceleyen bir araştırmaya rastlanmamıştır. Bu araştırma ile iki farklı ölçek kullanılarak daha önce yapılmamış özgün bir araştırma yoluyla bu alanda literatüre bir katk1 sağlanması umulmaktadır. $\mathrm{Bu}$ araştırmanın amacı, öğretmen algılarına göre örgütsel güç mesafesi ile örgütsel sinerji düzeyi arasındaki ilişkinin incelenmesidir. Bu amaç hususunda, araştırma kapsamında yanıtı aranan sorular aşağıda verilmiştir:

- Öğretmenlerin örgütsel güç mesafesi ve örgütsel sinerji düzeyleri arasında anlamlı bir ilişki var midir?

- Öğretmenlerin, örgütsel sinerji düzeyine ilişkin görüşleri sosyo-demografik değişkenlere göre farklıl1k göstermekte midir?

- Öğretmenlerin, örgütsel sinerji alt boyutları sosyo-demografik değişkenlere göre farklılık göstermekte midir?

- Öğretmenlerin örgütsel güç mesafesine ilişkin görüşleri sosyo-demografik değişkenlere göre farkl111k göstermekte midir?

- Öğretmenlerin, örgütsel güç mesafesi alt boyutları sosyo-demografik değişkenlere göre farklılık göstermekte midir?

\section{YÖNTEM}

Öğretmenlere yönelik örgütsel sinerji ve örgütsel güç mesafesi arasındaki ilişkiyi belirlemeye yönelik bu çalışmada nicel araştırma yöntemlerinden ilişkisel tarama modeli kullanılmıştır. Araştırmanın evrenini 2018-2019 eğitim ve öğretim y1lında İstanbul ili Zeytinburnu ilçesinde ilkokul, ortaokul ve liselerde görevini eda eden toplam 2635 öğretmen oluşturmaktadır. Araştırmanın örneklemini belirlemek için seçkisiz basit tesadüfi örnekleme yöntemi kullanılmıştır. Çalışmanın örneklem büyüklüğü 0,05 anlam 
düzeyinde 350 olarak hesaplanmıştır. Ölçeklerin tümüne ulaşılamaması ya da eksik, hatalı doldurulma olasılıkları hesaba katarak evrenin bütününe ulaşmayı amaçlamış ve 370 öğretmen araştırmanın örneklemini oluşturmuştur. Araştırma kapsamı doğrultusunda, katılması gerekenden daha fazla öğretmen araştırmaya katılmıştır. Dönmeyen anketler, girilen ve eksik ve hatalı verilerden dolayı ilgili analizler 330 kişi üzerinden yapılmıştır. İstanbul'da Millî Eğitim Bakanlığı'na bağlı okullarda görev yapan öğretmenlere; okul yöneticisinin karşılaştığı birtakım problemler hakkında nasıl bir yol ve yöntem izlediği görmek amacıyla planlanmıştır.

Araştırmanın gerektirdiği verilerin toplanması için üç bölümden oluşan bir form kullanılmıştır. Birinci bölümünde öğretmenlerin demografik verilerine ilişkin Kişisel Bilgi Formu, ikinci bölümde Örgütsel Sinerji Ölçeği, üçüncü bölümde ise Örgütsel Güç Mesafesi Ölçeği kullanılmıştır. Kişisel Bilgi Formunu araştırmacılar hazırlamış olup, çalışmanın örneklemini oluşturan öğretmenlere hazırlanan form verilerek bilgileri girmeleri sağlanmıştır. Kişisel Bilgi Formu bölümünde öğretmenlerin; cinsiyet (Kadın, Erkek), yaş (20-30, 31-40, 41-50, 51 ve üzeri), branș (Sınıf veya Branş öğretmeni) ve öğretmenlik deneyimini (1-5, 6$10,11-15,16-20,21-25,25$ yıl ve üzeri) ortaya koyan dört sorudan oluşmaktadır.

Bu araştırmada öğretmenlere Örgütsel Güç Mesafesi Ölçeği uygulanmıştır. Yorulmaz ve arkadaşlarının (2018) geliştirdiği Örgütsel Güç Mesafesi Ölçeğinde; gücü kabullenme, gücü araçsal kullanma, güce razı olma ve gücü meşrulaştırma olmak üzere dört alt faktör bulunmaktadır. Bu alt faktörlere ait değerler, demografik verilerden, yaş, cinsiyet ve kıdeme göre incelenmiştir. Bu alt faktörler ile demografik veriler arasında herhangi bir ilişki olup olmadı̆̆ını belirlemeye çalışılmıştır.

Öğretmenlerin sinerji düzeyini ölçmek amacıyla Akpolat ve Levent (2018) tarafından geliştirilen Örgütsel Sinerji Ölçeğinin; etkileşim ve takdir, strateji, bütünleşme, güncellenme ve güçlenme olmak üzere dört alt faktörü bulunmaktadır.

Elde edilen verilerin analizi aşamasında IBM SPSS 22 paket programı kullanılmıştır. Araştırmanın demografik bulgularının tespiti için frekans analizi yapılmıştır. Araştırmada kullanılan her iki ölçek içinde faktör analizi yapılarak ölçeklerin alt boyutları elde edilmiştir. Bulunan bu alt boyutların güvenirliğini test etmek için Cronbach Alfa güvenirlik katsayısı kullanılmıştır. Verilerin normal dağılımdan gelip gelmediğinin incelenmesi için Kolmogorov-Smirnov testi yapılmıştır. Ayrıca örneklem sayısı 35 'ten büyük olduğu için merkezi limit teoremi gereğince verilerin analizi aşamasında parametrik test istatistikleri kullanılmıştır. İki bağımsız grup için farklılaşma testlerinde bağımsız örneklem t-testi kullanılırken, ikiden fazla bağımsız grup karşılaştırmalarında ise ANOVA testi kullanılmıştır. Grup varyanslarının homojenliği ise Levene testi yardımı ile doğrulanmıştır. Anlamlı farklılık bulunan grupların tespitinde ise çoklu karşılaştırma testlerinde LSD testi kullanılmıştır.

\section{BULGULAR}

Araştırmaya katılın kişilerin demografik özellerinin tespit edilmesi için frekans analizi yapılmıştır. Frekans analizinin sonuçları Tablo 1'de verilmiştir. 
Tablo 1. Katılımcıların Demografik Özellikleri

\begin{tabular}{|c|c|c|c|}
\hline \multicolumn{2}{|c|}{ Değişken (n: 330) } & \multirow{2}{*}{$\frac{\text { Frekans }}{212}$} & \multirow{2}{*}{$\frac{\text { Yüzde }(\%)}{64.2 \%}$} \\
\hline & Kadın & & \\
\hline Cinsiyet & Erkek & 118 & $35.8 \%$ \\
\hline \multirow{4}{*}{ Yaş } & $20-30$ & 176 & $53.3 \%$ \\
\hline & $31-40$ & 119 & $36.1 \%$ \\
\hline & $41-50$ & 29 & $8.8 \%$ \\
\hline & $51+$ & 6 & $1.8 \%$ \\
\hline \multirow{6}{*}{ Tecrübe } & $1-5$ y1l & 133 & $40.3 \%$ \\
\hline & 6-10 y1l & 94 & $28.5 \%$ \\
\hline & $11-15$ y1l & 62 & $18.8 \%$ \\
\hline & $16-20$ y1l & 21 & $6.4 \%$ \\
\hline & $21-25$ y1l & 11 & $3.3 \%$ \\
\hline & $25 \mathrm{y} 11+$ & 9 & $2.7 \%$ \\
\hline
\end{tabular}

Araştırmaya katılan öğretmenlerin \%64,2'si kadın, \%35,8'i erkektir. \%53,3'ü 20-30 yaş arasında, \%36,1'i 31-40 yaş arasında, $\% 8,8^{\prime} \mathrm{i} 41-50$ yaş arasında ve $\% 1,8^{\prime} \mathrm{i}$ ise 51 yaş ve üzerindedir. Öğretmenlerin $\% 40,3$ 'ü 1-5 yıl arasında, \%28,5'i 6-10 yıl arasında, \%18,8'i 11-15 yıl arasında, \%6,4'ü 16-20 yıl arasında, \%3,3'ü 21-25 yıl arasında, \%2,7'si 25 yıl ve üzerinde deneyime sahip olduğu tespit edilmiştir. Ölçeklerin ve alt boyutlarının güvenilirlik analizi Cronbach Alfa değerleri Tablo 2'de verilmiştir.

Tablo 2. Güvenilirlik analizi

\begin{tabular}{lcc}
\hline Ölçek & Cronbach Alfa & N \\
\hline Örgütsel Sinerji Ölçeği & $\mathbf{. 9 2 3}$ & $\mathbf{2 9}$ \\
- Etkileşim ve Takdir Etme & .864 & 10 \\
- Bütünleşme & .870 & 9 \\
- Strateji & .816 & 6 \\
- Güncellenme ve Güçlenme & .741 & 4 \\
Örgütsel Güç Ölç̧ği & $\mathbf{. 8 3 3}$ & $\mathbf{2 0}$ \\
- Gücü Araçsal Kullanma & .841 & 6 \\
- Gücü Kabullenme & .794 & 8 \\
- Gücü Meşrulaştırma & .514 & 3 \\
- Güce Razı Olma & .572 & 3 \\
\hline
\end{tabular}

Araştırmada belirlenen birinci probleme göre; "öğretmenlerin örgütsel güç mesafesi ve örgütsel sinerji düzeyleri arasında anlamlı bir ilişki var mıdır?”. Probleme yönelik yapılan araştırmalarda anlamlı bir ilişki tespit edilememiştir. Araştırmada belirlenen ikinci probleme göre "öğretmenlerin, örgütsel sinerji düzeyine ilişkin görüşleri sosyo-demografik değişkenlere göre farklılık göstermekte midir?”. Probleme yönelik yapılan testlerde anlamlı bir ilişki tespit edilememiştir. Ancak ikinci alt probleme yönelik yapılan testlerde sadece kıdeme göre anlamlı bir farklılık tespit edilmiştir. Yapılan ANOVA analizi sonuçları Tablo 3'te verilmiştir. 
Tablo 3. Örgütsel sinerji düzeylerinin kıdeme göre ANOVA testi sonuçları

\begin{tabular}{|c|c|c|c|c|c|c|}
\hline Kıdem Boyutu & & $\begin{array}{l}\text { Kareler } \\
\text { Toplamı }\end{array}$ & s.d & $\begin{array}{c}\text { Kare } \\
\text { Ortalamas1 }\end{array}$ & $\mathrm{F}$ & p-değeri \\
\hline \multirow{3}{*}{$\begin{array}{l}\text { Etkileşim ve } \\
\text { Takdir }\end{array}$} & Gruplar Arası & 165.812 & 5 & 33.162 & \multirow{3}{*}{.932} & \multirow{3}{*}{.461} \\
\hline & Gruplar İçi & 11353.880 & 319 & 35.592 & & \\
\hline & Toplam & 11519.692 & 324 & & & \\
\hline \multirow{3}{*}{ Bütünleşme } & Gruplar Arası & 270.956 & 5 & 54.191 & \multirow{3}{*}{1.561} & \multirow{3}{*}{.171} \\
\hline & Gruplar İçi & 11072.447 & 319 & 34.710 & & \\
\hline & Toplam & 11343.403 & 324 & & & \\
\hline \multirow{3}{*}{ Strateji } & Gruplar Arası & 217.845 & 5 & 43.569 & \multirow{3}{*}{3.049} & \multirow{3}{*}{.011} \\
\hline & Gruplar İçi & 4586.357 & 321 & 14.288 & & \\
\hline & Toplam & 4804.202 & 326 & & & \\
\hline \multirow{3}{*}{$\begin{array}{l}\text { Güncellenme } \\
\text { ve Güçlenme }\end{array}$} & Gruplar Arası & 77.835 & 5 & 15.567 & \multirow{3}{*}{2.078} & \multirow{3}{*}{.068} \\
\hline & Gruplar İçi & 2405.034 & 321 & 7.492 & & \\
\hline & Toplam & 2482.869 & 326 & & & \\
\hline
\end{tabular}

ANOVA testi sonuçlarına göre sadece Strateji alt boyutu (p-değeri $(0,011)<0,05)$ sosyo-demografik değişkenlerden kıdeme göre farklılık gösterdiği tespit edilmiştir. Strateji alt boyutunda hangi kıdem yılı grubunun veya gruplarının farklılık gösterdiğini anlamak için çoklu karşılaştırma testleri yapılmıştır. Test sonuçları Tablo 4'te verilmiştir.

Tablo 4. Örgütsel sinerji alt boyutlarından stratejinin kıdeme göre anlamlılık değerleri

\begin{tabular}{|c|c|c|c|c|c|c|c|}
\hline \multicolumn{2}{|c|}{ Bağımlı Değişken } & \multirow{2}{*}{$\begin{array}{l}\text { Kidem } \\
\text { Grubu }\end{array}$} & \multirow{2}{*}{$\begin{array}{l}\text { Ort. } \\
\text { Farklar } \\
\text { (I-J) }\end{array}$} & \multirow{2}{*}{$\begin{array}{l}\text { Std. } \\
\text { Hata }\end{array}$} & \multirow{2}{*}{ p-değeri } & \multicolumn{2}{|c|}{ \%95 Güven } \\
\hline & & & & & & Alt Sinir & Üst Sin11 \\
\hline \multirow{5}{*}{ Strateji } & \multirow{5}{*}{$1-5$ y1l } & $6-10 \mathrm{y} 11$ & $1,76940^{*}$ & .50934 & .001 & .7673 & 27715 \\
\hline & & $11-15$ & $1,48145^{*}$ & .5878 & .012 & .3249 & 26380 \\
\hline & & $16-20$ y1l & .69812 & .90654 & .442 & -10854 & 24816 \\
\hline & & $21-25 \mathrm{y} 11$ & -.02461 & 118588 & .983 & -23577 & 23085 \\
\hline & & $25 \mathrm{y} 11+$ & -.19632 & 130190 & .880 & -27577 & 23650 \\
\hline
\end{tabular}

* 0.05 anlaml111k düzeyinde farkl111k gösteren gruplar

Çoklu karşılaştırma testi sonucunda p-değeri 0,05 'ten küçük olan ikili karşılaştırma grupları arasında anlamlı farklılık tespit edilmiştir. Anlamlı farklılık gösteren 1-5 yıl kıdem grubu ile 6-10 y1l kıdem grubu ve 1-5 yıl kıdem grubu ile 11-15 yıl kıdem grupları arasında olduğu tespit edilmiştir. Araştırmada belirlenen ikinci probleme göre; "öğretmenlerin, örgütsel güç mesafesi düzeylerine ilişkin görüşleri sosyo-demografik değişkenlere göre farklılık göstermekte midir?”. Probleme yönelik yapılan testlerde anlamlı bir ilişki tespit edilememiştir. Ancak üçüncü alt probleme yönelik yapılan testlerde sadece kıdeme göre anlamlı bir farklılık tespit edilmiştir. Yapılan ANOVA analizi sonuçları Tablo 5'te verilmiştir. 
Tablo 5. Örgütsel güç mesafesi düzeylerinin kıdeme göre ANOVA testi sonuçları

\begin{tabular}{llccccc}
\hline Alt Boyutlar & & Kareler Toplamı & s.d & Kare Ortalamas1 & F & p-değeri \\
\hline Gücü Araçsal & Gruplar Arasında & 18772 & 5 & 3754 & & \\
Kullanma & Gruplar İçinde & 220535 & 315 & .700 & 5363 & $\mathbf{. 0 0 0}$ \\
& Toplam & 239307 & 320 & & & \\
Gücü Kabullenme & Gruplar Arasında & 3418 & 5 & .684 & & \\
& Gruplar İçinde & 154640 & 319 & .485 & 1410 & .220 \\
& Toplam & 158058 & 324 & & & \\
Gücü Meşrulaştırma & Gruplar Arasında & 6145 & 5 & 1229 & & \\
& Gruplar İçinde & 167223 & 319 & .524 & 2344 & $\mathbf{. 0 4 1}$ \\
& Toplam & 173368 & 324 & & & \\
Güce Razı Olma & Gruplar Arasında & 7631 & 5 & 1526 & 2675 & $\mathbf{. 0 2 2}$ \\
& Gruplar İçinde & 183156 & 321 & .571 & & \\
\hline & Toplam & 190788 & 326 & & & \\
\hline
\end{tabular}

ANOVA testinin sonuçlarına göre Gücü Araçsal Kullanma, Gücü Meşrulaştırma ve Güce Razı Olma alt boyutlarının p-değerleri $[(0,000),(0,041),(0,022)], 0,05$ anlamlılık düzeyinden küçük olduğundan bu alt boyutlar kıdem gruplarına göre anlamlı farklılık gösterdiği tespit edilmiştir. Alt boyutlardan gücü araçsal kullanmanın hangi kıdem yılı grubunda veya gruplarında farklılık gösterdiğini anlamak için çoklu karşılaştırma testleri yapılmıştır. Test sonuçları Tablo 6'da verilmiştir.

Tablo 6. Örgütsel güç mesafesi alt boyutlarından gücü araçsal kullanmanın kıdeme göre anlamlılık değerleri

\begin{tabular}{|c|c|c|c|c|c|c|c|}
\hline \multirow{2}{*}{\multicolumn{3}{|c|}{ Bağımlı Değişken }} & \multirow{2}{*}{$\begin{array}{l}\text { Ortalama } \\
\text { Farklar (1-j) }\end{array}$} & \multirow{2}{*}{ Std. Sapma } & \multirow{2}{*}{ p-değeri } & \multicolumn{2}{|c|}{ \%95 Güven Düzeyi } \\
\hline & & & & & & Alt Sinır & Üst Sinır \\
\hline \multirow{25}{*}{$\begin{array}{l}\text { Gücü } \\
\text { Araçsal } \\
\text { Kullanma }\end{array}$} & \multirow{5}{*}{$1-5$ y1l } & 6-10 y1l & -.11588 & .11401 & .310 & -.3402 & .1084 \\
\hline & & $11-15 \mathrm{y} 1 \mathrm{l}$ & -.08699 & .13181 & .510 & -.3463 & .1724 \\
\hline & & $16-20 \mathrm{y} 11$ &, $50866^{*}$ & .19658 & .010 & .1219 & .8954 \\
\hline & & $21-25$ y1l & $1,00000^{*}$ & .26258 & .000 & .4834 & 15.166 \\
\hline & & $25 \mathrm{y} 11+$ & .33902 & .30466 & .267 & -.2604 & .9384 \\
\hline & \multirow{5}{*}{$6-10$ y1l } & $1-5 \mathrm{y} 11$ & .11588 & .11401 & .310 & -.1084 & .3402 \\
\hline & & $11-15 \mathrm{y} 11$ & .02889 & .14059 & .837 & -.2477 & .3055 \\
\hline & & $16-20 \mathrm{y} 11$ &, $62454^{*}$ & .20256 & .002 & .2260 & 10.231 \\
\hline & & $21-25 \mathrm{y} 11$ & $1,11588^{*}$ & .26710 & .000 & .5904 & 16.414 \\
\hline & & $25 \mathrm{y} 11+$ & .45490 & .30856 & .141 & -.1522 & 10.620 \\
\hline & \multirow{5}{*}{$11-15$ y1l } & $1-5 \mathrm{y} 11$ & .08699 & .13181 & .510 & -.1724 & .3463 \\
\hline & & $6-10$ y1l & -.02889 & .14059 & .837 & -.3055 & .2477 \\
\hline & & $16-20 \mathrm{y} 11$ &, $59565^{*}$ & .21309 & .006 & .1764 & 10.149 \\
\hline & & $21-25 \mathrm{y} 11$ & $1,08699^{*}$ & .27517 & .000 & .5456 & 16.284 \\
\hline & & $25 \mathrm{y} 1 \mathrm{l}+$ & .42601 & .31557 & .178 & -.1949 & 10.469 \\
\hline & \multirow{5}{*}{$16-20 \mathrm{y} 11$} & $1-5 \mathrm{y} 11$ &,$- 50866^{*}$ & .19658 & .010 & -.8954 & -.1219 \\
\hline & & $6-10$ y1l &,$- 62454^{*}$ & .20256 & .002 & -10.231 & -.2260 \\
\hline & & $11-15$ y1l &,$- 59565^{*}$ & .21309 & .006 & -10.149 & -.1764 \\
\hline & & $21-25$ y1l & .49134 & .31142 & .116 & -.1214 & 11.041 \\
\hline & & $25 \mathrm{y} 11+$ & -.16964 & .34764 & .626 & -.8536 & .5143 \\
\hline & \multirow{5}{*}{$21-25$ y1l } & $1-5 \mathrm{y} 11$ & $-1,00000^{*}$ & .26258 & .000 & -15.166 & -.4834 \\
\hline & & $6-10$ y1l & $-1,11588^{*}$ & .26710 & .000 & -16.414 & -.5904 \\
\hline & & $11-15 \mathrm{y} 1 \mathrm{l}$ & $-1,08699^{*}$ & .27517 & .000 & -16.284 & -.5456 \\
\hline & & $16-20 \mathrm{y} 11$ & -.49134 & .31142 & .116 & -11.041 & .1214 \\
\hline & & $25 \mathrm{y} 11+$ & -.66098 & .38879 & .090 & -14.259 & .1040 \\
\hline
\end{tabular}


* 0.05 anlaml111k düzeyinde farkl111k gösteren gruplar

Çoklu karşılaştırma testi sonuçlarına göre Gücü Araçsal Kullanma alt boyutu yaş kıdemleri arasında 1-5 y1l ile 16-20 ve 21-25 kıdem grupları, 6-10 ile 16-20 ve 21-25 kıdem gruplar1, 11-15 y1l ile 16-20 ve 2125 kıdem grupları, 16-20 ile 1-5 y11, 6-10 y1l ve 11-15 y1l k1dem grupları, 21-25 y1l ile 1-5 y1l, 6-10 y1l ve 11-15 yıl kıdem grupları arasında farklılık vardır. Öğretmenlerin kıdem yılları arttıkça Gücü Araçsal Kullanma puanları düşmektedir. Yani yeni öğretmenler kıdemli öğretmenlere nazaran Gücü Araçsal Kullanma puanı olarak daha yüksek seviyededir. Alt boyutlardan gücü meşrulaştırmanın hangi kıdem yılı grubunda veya gruplarında farklılık gösterdiğini anlamak için çoklu karşılaştırma testleri yapılmıştır. Test sonuçları aşağıda Tablo 7'de verilmiştir.

Tablo 7. Örgütsel güç mesafesi alt boyutlarından gücü meşrulaştırmanın kıdeme göre anlamlılık değerleri

\begin{tabular}{|c|c|c|c|c|c|c|c|}
\hline \multirow{2}{*}{\multicolumn{3}{|c|}{ Bağımlı Değişken }} & \multirow{2}{*}{$\begin{array}{c}\text { Ortalama } \\
\text { Farklar }(1-\mathrm{j})\end{array}$} & \multirow{2}{*}{ Std. Sapma } & \multirow{2}{*}{ p-değeri } & \multicolumn{2}{|c|}{ \%95 Güven Düzeyi } \\
\hline & & & & & & Alt Sinir & Üst Sinır \\
\hline \multirow{15}{*}{$\begin{array}{l}\text { Gücü } \\
\text { Meşrulaştırma }\end{array}$} & \multirow{5}{*}{$1-5$ y1l } & $6-10$ y1l & $30699^{*}$ & .09817 & .002 & .1138 & .5001 \\
\hline & & $11-15$ y1l & .04363 & .11223 & .698 & -.1772 & .2644 \\
\hline & & $16-20$ y1l & .14928 & .17019 & .381 & -.1856 & .4841 \\
\hline & & $21-25$ y1l & .37150 & .23753 & .119 & -.0958 & .8388 \\
\hline & & $25 \mathrm{y} 11+$ & .11224 & .24949 & .653 & -.3786 & .6031 \\
\hline & \multirow{5}{*}{$6-10$ y1l } & $1-5 \mathrm{y} 11$ &,$- 30699^{*}$ & .09817 & .002 & -.5001 & -.1138 \\
\hline & & $11-15 \mathrm{y} 11$ &,$- 26335^{*}$ & .11929 & .028 & -.4980 & -.0287 \\
\hline & & $16-20 \mathrm{y} 1 \mathrm{l}$ & -.15771 & .17493 & .368 & -.5019 & .1864 \\
\hline & & $21-25$ y1l & .06452 & .24095 & .789 & -.4095 & .5386 \\
\hline & & $25 \mathrm{y} 11+$ & -.19474 & .25275 & .442 & -.6920 & .3025 \\
\hline & \multirow{5}{*}{$11-15 \mathrm{y} 11$} & $1-5$ y1l & -.04363 & .11223 & .698 & -.2644 & .1772 \\
\hline & & $6-10$ y1l & $26335^{*}$ & .11929 & .028 & .0287 & .4980 \\
\hline & & $16-20$ y1l & .10565 & .18318 & .565 & -.2548 & .4660 \\
\hline & & $21-25$ y1l & .32787 & .24701 & .185 & -.1581 & .8138 \\
\hline & & $25 \mathrm{y} 11+$ & .06861 & .25853 & .791 & -.4400 & .5773 \\
\hline
\end{tabular}

* 0.05 anlaml11ık düzeyinde farkl111k gösteren gruplar

Gücü Meşrulaştırma alt boyutu mesleki kıdem sürelerine göre 1-5 yıl ve 6-10 yıl kıdem grupları farklı1ık gösterdiği tespit edilmiştir. 1-5 yıl kıdem grubunun Gücü Meşrulaştırma puanı daha yüksektir. Ayrıca 6-10 yıl kıdem grubu ile 11-15 yıl kıdem grubu arasında da anlamlı farklılık söz konusudur. 11-15 yıl kıdem grubunun Gücü Meşrulaştırma Puanı daha yüksektir. Alt boyutlardan güce razı olmanın hangi kıdem yılı grubunda veya gruplarında farklılık gösterdiğini anlamak için çoklu karşılaştırma testleri yapılmıştır. Test sonuçları aşağıda Tablo 8'de verilmiştir.

Güce Razı Olma alt boyutunun mesleki kıdem sürelerine göre 1-5 yıl kıdem grubu ile 11-15 yıl ve 21-25 yıl kıdem grupları arasında farklılık söz konusudur. 1-5 yıl kıdem grubunun puanı daha düşüktür. 6-10 yıl k1dem grubu ile 11-15 y1 kıdem grubu arasında anlamlı farkl11ı söz konusudur. 11-15 y1l kıdem grubunun puanı daha yüksektir. 11-15 yıl kıdem grubu ve 16-20 yıl kıdem grubu arasında anlamlı farklılık söz konusudur. 11-15 yıl kıdem grubunun puanı daha büyüktür. 
Tablo 8. Örgütsel güç mesafesi alt boyutlarından gücü meşrulaştırmanın kıdeme göre anlamlılık değerleri

\begin{tabular}{|c|c|c|c|c|c|c|c|}
\hline \multirow{2}{*}{\multicolumn{3}{|c|}{ Bağımlı Değişken }} & \multirow{2}{*}{$\begin{array}{c}\text { Ortalama } \\
\text { Farklar }(1-\mathrm{j})\end{array}$} & \multirow{2}{*}{ Std. Sapma } & \multirow{2}{*}{ p-değeri } & \multicolumn{2}{|c|}{ \%95 Güven Düzeyi } \\
\hline & & & & & & Alt Sinir & Üst Sinır \\
\hline \multirow{25}{*}{ Güce Razı Olma } & \multirow{5}{*}{$1-5$ y1l } & $6-10 \mathrm{y} 11$ & -.10451 & .10226 & .308 & -.3057 & .0967 \\
\hline & & $11-15 \mathrm{y} 1 \mathrm{l}$ &,$- 37345^{*}$ & .11695 & .002 & -.6035 & -.1434 \\
\hline & & $16-20$ y1l & .01479 & .17746 & .934 & -.3343 & .3639 \\
\hline & & $21-25$ y1l &,$- 47727^{*}$ & .23705 & .045 & -.9436 & -.0109 \\
\hline & & $25 \mathrm{y} 1+$ & -.14394 & .26023 & .581 & -.6559 & .3680 \\
\hline & \multirow{5}{*}{ 6-10 y1l } & $1-5$ y1l & .10451 & .10226 & .308 & -.0967 & .3057 \\
\hline & & $11-15$ y1l &,$- 26893^{*}$ & .12445 & .031 & -.5138 & -.0241 \\
\hline & & $16-20 \mathrm{y} 1 \mathrm{l}$ & .11930 & .18250 & .514 & -.2397 & .4783 \\
\hline & & $21-25$ y1l & -.37276 & .24084 & .123 & -.8466 & .1011 \\
\hline & & $25 \mathrm{y} 11+$ & -.03943 & .26369 & .881 & -.5582 & .4794 \\
\hline & \multirow{5}{*}{ 11-15 y1l } & $1-5$ y1l &, $37345^{*}$ & .11695 & .002 & .1434 & .6035 \\
\hline & & $6-10$ y1l & ,26893* & .12445 & .031 & .0241 & .5138 \\
\hline & & $16-20 \mathrm{y} 11$ & ,38824* & .19111 & .043 & .0122 & .7642 \\
\hline & & $21-25$ y1l & -.10383 & .24744 & .675 & -.5906 & .3830 \\
\hline & & $25 \mathrm{y} 11+$ & .22951 & .26972 & .395 & -.3011 & .7602 \\
\hline & \multirow{5}{*}{$16-20$ y1l } & $1-5$ y1l & -.01479 & 列. & .934 & -.3639 & .3343 \\
\hline & & $6-10$ y1l & -.11930 & .18250 & .514 & -.4783 & .2397 \\
\hline & & $11-15$ y1l &,$- 38824^{*}$ & .19111 & .043 & -.7642 & -.0122 \\
\hline & & $21-25$ y1l & -.49206 & .28114 & .081 & -10.452 & .0611 \\
\hline & & $25 \mathrm{y} 11+$ & -.15873 & 30095 & .598 & -.7508 & .4333 \\
\hline & \multirow{5}{*}{$21-25$ y1l } & $1-5$ y1l & ,47727* & .23705 & .045 & .0109 & .9436 \\
\hline & & 6-10 y1l & .37276 & .24084 & .123 & -.1011 & .8466 \\
\hline & & $11-15$ y1l & .10383 & .24744 & .675 & -.3830 & .5906 \\
\hline & & $16-20$ y1l & .49206 & .28114 & .081 & -.0611 & 10.452 \\
\hline & & $25 \mathrm{y} 11+$ & .33333 & .33951 & .327 & -.3346 & 10.013 \\
\hline
\end{tabular}

* 0.05 anlaml11ık düzeyinde farklılık gösteren gruplar

Araştırmada elde edilen bulgulara göre birinci probleme yönelik bir ilişki tespit edilememiştir. İkinci problemin alt probleminde ilişki tespit edilmiştir. Buna göre sosyo-demografik değişkenlerden öğretmenlerde kıdem süresi örgütsel sinerji düzeyinin alt boyutu olan stratejiye etki etmektedir. Benzer şekilde üçüncü problemin alt probleminde ilişki tespit edilmiştir. Buna göre sosyo-demografik değişkenlerden öğretmenlerde kıdem süresi örgütsel güç mesafesi alt boyutlarından güce razı olma, gücü meşrulaştırma ve gücü araçsal kullanmaya etki etmektedir.

\section{SONUÇ}

Araştırma kapsamında İstanbul sınırları içerisinde Millî Eğitim Bakanlığına bağlı okullarda görev alan öğretmenlerin örgütsel sinerji algıları ile örgütsel güç mesafesi algılarının arasındaki ilişki ve sosyodemografik değişkenlerin örgütsel sinerji ile örgütsel mesafe algılarına etki edip etmediği tespit edilmeye çalışılmıştır. Elde edilen bulgulara göre öğretmenlerin örgütsel sinerji algıları ile örgütsel güç mesafesi algıları arasında bir ilişki tespit edilememiştir. Buna göre öğretmenlerin örgütsel sinerji düzeyleri örgütsel güç mesafesi düzeylerine göre bir farklılık göstermemektedir.

Araştırma kapsamında cevap aranan bir diğer problem olan öğretmenlerin örgütsel sinerji düzeylerinin sosyo-demografik değişkenlere göre anlamlı bir farklılık gösterip göstermemesidir. Yapılan testler sonucunda sosyo-demografik değişkenlerden olan kıdem süresi değişkeni ile örgütsel sinerji alt 
boyutlarından olan stratejinin arasında anlamlı bir farklılık tespit edilmiştir. Farklılığın 1-5 y1l arası kıdem grubunda olan ile 6-10 y1l arası k1dem grubunun ortalamaları ve 1-5 y1l arası k1dem grubunda olan ile 1115 yıl arası kıdem gruplarının ortalamaları arasında olduğu gözlemlenmiş̧tir. Bulgulara 1-5 yıl kıdem süresine sahip öğretmenlerin 6-10 yıl ve 11-15 yıl kıdem süresine sahip öğretmenlere göre strateji algıları daha yüksektir. Bu durumda 1-5 yıl arası kıdeme sahip öğretmenlerin daha uzun kıdeme sahip öğretmenlere göre yönetimin stratejisine olan algılarının daha yüksek olduğu söylenebilir.

Araştırmada Örgütsel Sinerji Ölçeğindeki ifadeler araştırmaya katılan öğretmenlerin yöneticilerine karşı bakış açılarına ilişkin ifadelerdir. Bu bulgulara göre; katılımcıların çoğunun, öğretmenlerin yönetici konumundaki insanların ne düşündüklerini önemsedikleri, yöneticilerine karşı daha fazla saygı duydukları ve yönetici konumundaki insanların bazı imtiyazlarının olmasını normal karşıladığ sonucuna varılmıştır.

Araştırma kapsamında cevap aranan bir diğer problem, öğretmenlerin örgütsel güç mesafesi düzeylerinin sosyo-demografik değişkenlere göre anlamlı bir farklılık gösterip göstermemesidir. Yapılan analizler sonucunda sosyo-demografik değişkenlerden olan kıdem süresi değişkeni ile örgütsel güç mesafesi alt boyutlarından olan gücü araçsal kullanmaya, meşrulaştırmaya ve razı olma arasında anlamlı bir farklılık tespit edilmiştir. Öğretmenlerin kıdem yılları gücü araçsal kullanmaya, meşrulaştırmaya ve razı olma puanları düşmektedir. Yani yeni öğretmenler kıdemli öğretmenlere nazaran gücü araçsal kullanmaya, meşrulaştırmaya ve razı olmaya inanmaktadır. Araştırmada genel olarak dikkat çeken durum 1-5 yıl arası kıdem yılına sahip olan diğer tüm öğretmen gruplarına göre daha yüksek oranda anlamlı farklılık kaydetmiş olmasıdır. Örgütsel güç mesafesi kapsamında kıdeme göre tespit edilen farklılıklar literatürdeki çalışmalarla örtüşmediği görülmektedir (Titrek ve Zafer, 2009; Kayalı, 2011; Demir, 2017). Literatürdeki çalışmalarda örgütsel güç mesafesinin sosyo-demografik değişkenlere göre anlamlı bir farklılığın tespit edilmediği gözlemlenmektedir. Literatürde yapılan çalışmalara baktığımızda Memduhoğlu ve Turhan (2017), "Öğretmen görüşlerine göre ilköğretim okul müdürlerinin örgütsel güç kaynaklarını kullanma düzeyleri” adlı çalışmasında öğretmen fikirlerine göre okul müdürlerinin yönetim esnasında hangi örgütsel güç kaynağını tercih ettiklerini ve bu sosyal güç kaynaklarının kullanım düzeylerini incelemiştir. Yapılan analizler neticesinde okul müdürlerinin en çok başvurduğu güç kaynağı "uzmanlık gücü", en düşük seviyede tercih ettikleri güç ise "zorlayıcı güç" olduğu bulunmuştur. Aslantaş ve Uğur (2018), "Öğretmenlerin algılarına göre yöneticilerin sahip oldukları örgütsel güç kaynakları düzeyi" adlı çalışmasında öğretmenlerin okul yöneticilerine karşı sahip olduğu örgütsel güç kaynaklarının düzeyi incelenmiştir. Bu araştırma sonucunda, yöneticilerin en çok "yasal gücü" tercih ettikleri; en az "zorlayıc1 güç” olduğu görülmüş̧ür. Bu noktada Kayalı (2011)'in çalışmasında sosyo-demografik değişkenlerden olan cinsiyete göre örgütsel güç mesafesinde anlamlı bir farklılık tespit edilirken bu araştırma sonuçları ile örtüşmediği gözlemlenmektedir.

Bu araştırmada öğretmenlerin Örgütsel Güç Mesafesi Ölçeği sonuçlarına göre Gücü Araçsal Kullanma alt boyutu ile kıdem yılı arasında anlamlı bir ilişki bulunmuştur. Kıdem yılı arttıkça Gücü Araçsal Kullanma puanları düşmekte, kıdem yılı düştükçe Gücü Araçsal Kullanma puanları artmaktadır. Ayrıca Kıdem Yı1ı ve Gücü Meşrulaştırma arasında da anlamlı bir ilişki bulunmuştur. Kıdem yılı arttıkça Gücü meşrulaştırma puanları artmaktadır. Son olarak kıdem yılı ile Güce Razı Olma arasında pozitif yönde anlamlı bir ilişki bulunmaktadır. Kıdem yılı arttıkça Güce Razı Olma puanları artmaktadır. Bu bağlamda ilgili okul yönetimi tarafindan öğretmenlik mesleğinde tecrübeli ve tecrübesiz olanlar çeşitli seminerler aracıllğıyla bir araya getirilerek birbirleri ile fikir alışverişinde bulunabilirler. Mesleki tecrübesi yüksek olan öğretmenler deneyimlerini daha az tecrübesi olan öğretmenlerle paylaşabilirler. Daha az tecrübesi olan öğretmenler talep ve görüşlerini bildirerek, tecrübeli öğretmenlerin deneyimlerinden faydalanabilirler.

Bundan sonraki yapılacak çalışmalarda öğretmenlerin örgütsel güç mesafesi ve örgütsel sinerji düzeylerinin belirlenmesine yönelik nitel araştırma tekniklerinden yararlanılabilir. Aynı doğrultudaki araştırmaların özel okullar için de geliştirilmesi, devlet okulları ile özel okulların kıyaslanması tavsiye edilebilir. Ayrıca bu araştırmanın bulgularından yararlanılarak, araştırmanın kapsamı daha da genişletilerek, derinlemesine bir araştırma projesi yapılabilir. 


\section{KAYNAKÇA}

Açıkalın, Ş. (1993). Öğretmenlerin okul müdürlerini etkileme güçleri. Hacettepe Üniversitesi Eğitim Fakültesi Dergisi, 9(9), 183-192.

Akçay, A. (2003). Okul müdürleri öğretmenlerini etkileyebiliyor mu? Milli Eğitim Dergisi, 157, 121-136.

Akpolat, T. ve Levent, F. (2018). Öğretmenlere yönelik örgütsel sinerji ölçeği'nin geliştirilmesi. Mersin Üniversitesi Ĕ̈itim Fakültesi Dergisi, 14(2), 728-744

Altınkurt, Y., Yılmaz, K., Erol, E. ve Salalı, E. T. (2014). Okul müdürlerinin kullandığı güç kaynakları ile öğretmenlerin örgütsel sinizm algıları arasındaki ilişki. Öğretmen Ĕ̆itimi ve Ĕgitimcileri Dergisi, 3(1), 25 52 .

Argon, T., Yıldırım, F. A. ve Kurt, A. (2014). Yöneticilerin sahip olduğu güç stilleri ve iş çevrelerine uyuma ilişkin öğretmen görüşleri. Bartın Üniversitesi Eğitim Fakültesi Dergisi, 3(2), 26-48

Aslanargun, E. (2009). "İlköğretim ve lise müdürlerinin okul yönetiminde kullandı̆̆g güç türleri”. (Yayınlanmamış Doktora tezi), Ankara Üniversitesi, Ankara.

Aydın, F. (2016). "Ortaokul yöneticilerinin kullandıkları örgütsel güç türleri ve ögretmenlerin örgütsel sessizlik davranışları”. (Yayınlanmamış yüksek lisans tezi), Pamukkale Üniversitesi Eğitim Bilimleri Enstitüsü, Denizli.

Can, N. (Ed.). (2018). Kuram ve uygulamada eğitim yönetimi. Ankara: Pegem Akademi.

Can, H. (2011). Organizasyon ve yönetim. Ankara: Siyasal Kitabevi.

Cüceloğlu, D. (2008). İyi düşün doğru karar ver. İstanbul: Remzi Kitabevi.

Güney, S. (1999). Davranış bilimleri açısından Atatürk'ün liderliği. Ankara: Ocak Yayınları.

Uğurlu, C. T. ve Demir, A. (2014). Örgütsel vatandaşlık davranışının öncülü olarak okul yöneticilerinin kullandıkları güç kaynakları. Elektronik Sosyal Bilimler Dergisi, 15(56), 98-119.

Karaman, A. (2009). Profesyonel yöneticilerde güç yönetimi. İstanbul: Türkmen Kitabevi.

Kayalı, M. (2011). “Okul müdürlerinin kullandıkları güç kaynakları”. (Yayınlanmamış yüksek lisans tezi), Uşak Üniversitesi Sosyal Bilimler Enstitüsü, Uşak.

Koçel, T. (2015). Işsletme yöneticiliği. İstanbul: Beta Yayınc1lık.

Kutanış, R. Ö. (2014). Örgütlerde davranış bilimleri. Sakarya: Sakarya Kitabevi.

Lunenburg, F. C. ve Ornstein, A. C. (2013). Eğitim yönetimi. (Çev. Gökhan Arastaman), Ankara: Nobel Yayınları.

Özgener, Ş., Öğüt, A. ve Kaplan, M. (2008). İşgören-işveren ilişkilerinde yeni bir paradigma: Örgütsel sinizm, içinde Özdevecioğlu, M. ve Karadal, H., (Ed.) Örgütsel davranışta seçme konular: organizasyonların karanlı yönleri ve verimlilik azaltıcı davranışlar. Ankara: İlke Yayınevi.

Özaslan, G. (2006). "Eğitim yöneticilerinin güç tipi tercihlerinin değerlendirilmesi”. (Yayınlanmamış doktora tezi). Selçuk Üniversitesi Sosyal Bilimler Enstitüsü, Konya.

Polat, S. (2010). “Okul öncesi yöneticilerinin kullandıkları yönetsel güç kaynaklarına ilişkin ögretmen algıları ile ögretmen motivasyonu arasındaki ilişki”. (Yayınlanmamış yüksek lisans tezi), Yeditepe Üniversitesi Sosyal Bilimler Enstitüsü, İstanbul.

Raven, B. H. (2008). The bases of power and the power/interaction model of interpersonal influence. Analyses of Social Issues and Public Policy, 8(1), 1-22

Sofyalıoğlu, Ç. ve Aktaş, R. (2001). Kültürel farklılıkların uluslararası işletmelere etkisi. Yönetim ve Ekonomi: Celal Bayar Üniversitesi İktisadi ve İdari Bilimler Fakültesi Dergisi, 8(1), 75-92. 
Şimşek, M. Ş., Akgemci, T. ve Çelik, A. (2015). Davranış bilimlerine giriş ve örgütlerde davranış. Konya: Eğitim Yayınevi.

Taymaz, H. (2019). Okul yönetimi. Ankara: Pegem Yayınları,

Terzi, A. R. (2004). Üniversite öğrencilerinin güç mesafesi ve belirsizlikten kaçınma algıları üzerine bir araştırma. Afyon Kocatepe Üniversitesi Sosyal Bilimler Dergisi, 6(2), 65-76.

Turner, J. C. (2005). Explaining the nature of power: a three-process theory. European Journal of Social Psychology, 35, 1-22.

Yıldırım, A. ve Şimşek, H. (2018). Sosyal bilimlerde nitel araştırma yöntemleri. Ankara: Seçkin Yayıncilik.

Yorulmaz, Y. İ., Çolak, İ., Altınkurt, Y. ve Yılmaz, K. (2018). Örgütsel güç mesafesi ölçeği geçerlik ve güvenirlik çalışması. Trakya Eğitim Dergisi, 8(4), 671-686. 